An international conference Mental Illness in Old Age will be held at the University of Liverpool from 24-25 June 1993. Further information: Catherine Sherratt or Kathy Johnson, Institute of Human Ageing, University of Liverpool, PO Box 147, Liverpool L69 3BX (telephone 051794 5066/67; fax 051794 5077).

The Association for Psychoanalytic Psychotherapy in conjunction with the City University Counselling and Advisory Service will be holding a conference Providing for the Providers: Guarding the Health of the Health Care Professionals on 10 July 1993 in the Senate Suite, City University College Building. Further information: Sow Fun Pit-Dawson, Counselling and Advisory Service, City University, Northampton Square, London EC1V OHB (telephone 0714778094 ).

A seminar The Emotional Needs of Refugee Children and their Families: Implications for Professionals will be held on 26 June 1993 at the Tavistock Centre, 120 Belsize Lane, London NW3. Further information: MEDACT, 601 Holloway Road, London N194DJ (telephone 071272 2020).

A conference Children's Evidence in the Courts will be held on 24 June 1993 at The Slieve Donard Hotel, Newcastle, County Down, Northern Ireland. A workshop Risk-taking in Health and Social Services will be held on 22 June 1993 and one on Developing Witness Skills on 23 June 1993. Further information: Jill Elliott, Continuing Education Manager, Faculty of Law, University of Southampton, Southampton SO9 5NH (telephone 0703 592376; fax 0703 593024).

\section{Courses}

A course Individual Work with Children, Young People and Their Families in Varied Settings: a psychodynamic approach, organised by the University of Birmingham Centre for Postgraduate Psychiatry, will start in September 1993. Further information: Christine Neal at the Centre, Uffculme Clinic, Queensbridge Road, Moseley, Birmingham B13 8QD (telephone 021 442 4545).
Applications are invited for a one year, part-time Certificate in Psychodynamic Approaches to Practice, starting in October 1993. Further information and application forms: Jane Nicholson, Course Coordinator, Mental Health Research and Staff Development Unit, University of Manchester, Maths Tower, Oxford Road, Manchester M139PL (telephone 061275 5221).

Portman Clinic Courses: Child Sexual Abuse within the Family: an inter-agency perspective will run for three terms from October 1993-July 1994 on Thursdays from 2.00 to 3.30 p.m. Closing date for application: 14 June 1993. Further information: Dr Elif Gurisik, Consultant Psychotherapist, The Portman Clinic, 8 Fitzjohns Avenue, London NW3 5NA (telephone 071794 8262).

The University of Birmingham, School of Continuing Studies invite applications for a course in Counselling Supervision to commence in September 1993. This course is to run on five limited Saturdays in the Autumn term. Further information: Sue Wheeler, School of Continuing Studies, The University of Birmingham, Edgbaston, Birmingham B15 2TT (telephone 021414 5622).

A two year course in Psycho-therapeutic Approaches to Work with Children and Adolescents will be held at Guy's Hospital, London on Tuesday evenings, starting October 1993. Closing date: 25 June 1993. Further information and application forms: Linda Buckingham, Child Psychotherapist, Forest Hill Child Guidance Unit, The Jenner Health Centre, 203 Stanstead Road, London SE23 1HU.

A short course The Planning, Development, and Evaluation of Community Mental Health Services: a dynamic and practical approach will be held on 29 and 30 June 1993 at the Wolfson Lecture Theatre, Institute of Psychiatry. Further information: Mrs L. Wilding, Conference Office, Institute of Psychiatry, De Crespigny Park, Camberwell, London SE5 8AF (telephone 0717035411 , extension 3170 ; fax 071703 5796).

\title{
STUDY TOUR TO GERMANY IN 1993
}

The Study Tour Sub-Committee is proposing to arrange a week long Study Tour to Germany, 26 September to 3 October 1993. The tour will include visits to clinics, hospitals, university departments in Neustadt, Lübeck, Rostock, Kiel and Hamburg.

If you would like further information on this Tour, please contact the Public Education Department at the College. 